\title{
PENGUKURAN KONSTANTA DISOSIASI ASAM MONOETHANOLAMINE PADA SUHU $30-60^{\circ} \mathrm{C}$
}

\author{
Eleonora Amelia', Deasy R. Alwani' ${ }^{2}$, Sholeh Ma'mun ${ }^{3}$ \\ Jurusan Teknik Kimia, Fakultas Teknologi Industri, Universitas Islam Indonesia ${ }^{1,2,3)}$ \\ Jl. Kaliurang Km. 14,5 Sleman, Yogyakarta 55584 \\ Email : sholeh.mamun@uii.ac.id ${ }^{3}$
}

\begin{abstract}
Global warming caused by greenhouse gas emissions, e.g. carbon dioxide $\left(\mathrm{CO}_{2}\right)$, in the atmosphere is now becoming a very serious problem facing the world community. Carbon dioxide emission increase from year to year, thus a necessary effort to reduce $\mathrm{CO}_{2}$ is required. Amine-based absorption is one of the methods for post-combustion capture. Monoethanolamine (MEA) is commonly used for $\mathrm{CO}_{2}$ capture solvent. This study aims to measure protonation constant ( $p K_{a}$ ) of MEA from 30 to $60^{\circ} \mathrm{C}$ using the potentiometric titration method. The results show that the $p K_{a}$ values of $M E A$ are in general agree with the literature data. For instance, the $p K_{a}$ value of $M E A$ at $30^{\circ} \mathrm{C}$ is 9.83 and that obtained from the literature is 9.80. Comparison between those two values gives a deviation of $0.22 \%$.
\end{abstract}

Keywords : Global Warming, Monoethanolamine, $\mathrm{CO}_{2}$ Capture, pKa.

\section{PENDAHULUAN}

Pemanasan global adalah suatu proses meningkatnya suhu rata - rata atmosfer, laut, dan daratan Bumi. Intergovernmental Panel on Climate Change (IPCC) menyimpulkan bahwa sebagian besar peningkatan suhu rata - rata global sejak pertengahan abad ke-20 kemungkinan besar disebabkan oleh meningkatnya konsentrasi gas - gas rumah kaca akibat aktivitas manusia melalui efek rumah kaca (Alley, R., Climate Change, 2007). Perhitungan pemanasan global berdasarkan scenario SRES A2 dengan mengasumsikan tidak ada tindakan yang dilakukan untuk mengurangi emisi dapat dilihat pada gambar 1 (Torn, Margaret; Harte, John dan Harte, John; et al).

Indonesia menempati peringkat keempat di dunia sebagai penyumbang emisi karbon dioksida $\left(\mathrm{CO}_{2}\right)$ berdasarkan World Resources Institute (WRI). Emisi $\mathrm{CO}_{2}$ dapat meningkat pada tahun 2015 salah satunya disebabkan oleh kebakaran hutan dan revolusi industri. Pada tahun 2015, total emisi Indonesia berkisar sekitar 760 juta ton $\mathrm{CO}_{2}$ (tidak termasuk perubahan penggunaan lahan).

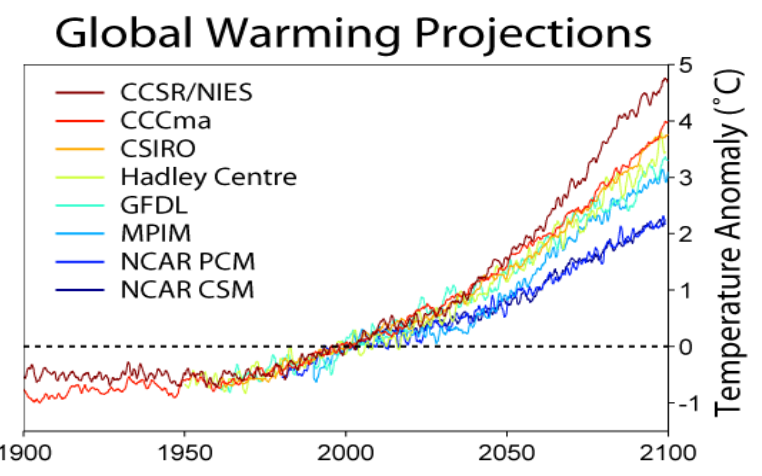

Gambar 1. Perhitungan Pemanasan Global pada Tahun 2001 dari Beberapa Model Iklim Berdasarkan Scenario SRES A2.

Metode $\mathrm{CO}_{2}$ Capture and Storage (CCS), merupakan salah satu metode yang cocok untuk diterapkan pada skala industri yang menghasilkan limbah $\mathrm{CO}_{2}$ dalam jumlah besar untuk mengurangi kadar konsentrasi $\mathrm{CO}_{2}$ dengan cara menyalurkan $\mathrm{CO}_{2}$ melalui pipa untuk diinjeksikan ke dalam bumi. Pada metode $\mathrm{CCS}, \mathrm{CO}_{2}$ diperangkap di dalam rongga-rongga pori batuan dalam waktu ratusan sampai ribuan tahun. Metode CCS dapat dikombinasikan dengan proses didesaknya hidrokarbon pada rongga - rongga pori batuan. 


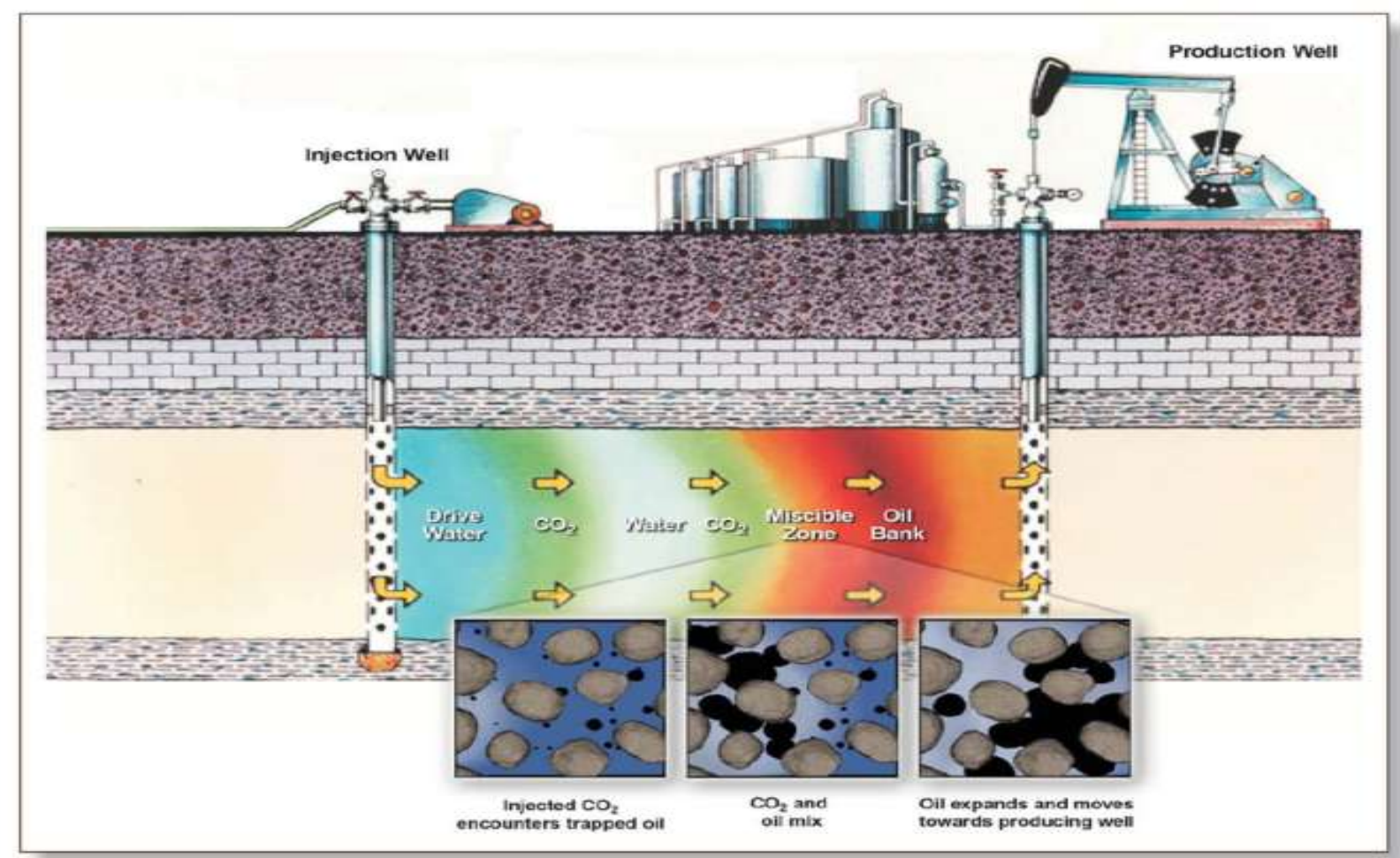

Gambar 2. Skema Kombinasi CCS dan EOR atau Lebih di Kenal dengan Nama $\mathrm{CO}_{2}$-EOR.

Proses tersebut dinamakan Proses $\mathrm{CO}_{2}-$ Enhanced Oil Recovery $\left(\mathrm{CO}_{2}\right.$-EOR) seperti yang dilihat pada gambar 2. Senyawa amina seperti MEA, DEA, dan MDEA sering digunakan sebagai absorben pada absorpsi $\mathrm{CO}_{2}$ karena memiliki kemampuan menyerap gas $\mathrm{CO}_{2}$ yang baik, laju absorpsi cepat, dan mudah untuk diregenerasi (Astarita, G.; D.W. Savage; A Bisio).

Senyawa amina merupakan absorben yang paling banyak digunakan pada proses absorpsi $\mathrm{CO}_{2}$, karena senyawa amina dapat bereaksi dengan $\mathrm{CO}_{2}$ membentuk senyawa kompleks (ion karbamat) dengan ikatan kimia yang lemah. Ikatan kimia ini dapat dengan mudah terputus dengan pemanasan (mild heating) sehingga regenerasi absorben senyawa amina dapat dengan mudah terjadi (Wang; et al).
Pada proses pemisahan gas $\mathrm{CO}_{2}$ di kolom absorber, gas alam dialirkan melalui bagian bawah kolom, sementara larutan MEA dialirkan melalui bagian atas kolom. Perpindahan gas $\mathrm{CO}_{2}$ dari gas alam ke larutan MEA dapat terjadi akibat adanya kontak antara gas dan MEA di dalam kolom.

Larutan MEA yang telah menyerap $\mathrm{CO}_{2}$ kemudian keluar melalui bagian bawah kolom untuk selanjutnya dikirim ke kolom regenerasi untuk melepaskan gas $\mathrm{CO}_{2}$ yang terikat. Untuk itu, data konstanta disosiasi asam (pKa) monoetanolamine sangat diperlukan dalam perancangan sebuah kolom absorber untuk menyelesaikan pemodelan matematis kesetimbangan uap - cair dan reaksi kimia antara $\mathrm{CO}_{2}$ dengan larutan MEA. Penelitian ini bertujuan untuk mengukur konstanta disosiasi asam (pKa) dari MEA pada kisaran suhu $30-60^{\circ} \mathrm{C}$. 


\section{METODE PENELITIAN}

\subsection{Alat dan Bahan}

Penelitian dilakukan di Laboratorium Penelitian Program Studi Teknik Kimia Universitas Islam Indonesia, Yogyakarta.

Alat - alat yang digunakan dalam penelitian ini dapat dilihat pada gambar 3 . Pada penelitian pengukuran konstanta disosiasi asam (pKa) MEA bahan - bahan yang digunakan antara lain Larutan Buffer $\mathrm{PH} 4$ dan $\mathrm{PH} 7$, MEA 98\%, $\mathrm{H}_{2} \mathrm{SO}_{4} 96 \%$, serta aquadest.

Pada gambar 3 Tingkat akurasi $\mathrm{pH}$ meter yang digunakan lebih dari 0,01 , tingkat akurasi thermometer digital TFA ${ }^{\circledR}>0,1^{0} \mathrm{C}$, neraca digital OHAUS ${ }^{\circledR}$ dengan tingkat ketelitian $>0,0001 \mathrm{~g}$.

\subsection{Variabel Proses}

Variabel tetap dalam penelitian ini adalah $10,217 \mathrm{~g} \mathrm{H}_{2} \mathrm{SO}_{4} 96 \%$ yang digunakan untuk membuat $\mathrm{H}_{2} \mathrm{SO}_{4}$ 0,1M dalam $1000 \mathrm{~mL}$ aquadest, $50 \mathrm{~mL}$ aquadest, 0,5g MEA 98\%. Variabel bebas yang digunakan dalam penelitian ini adalah variasi titran $\mathrm{H}_{2} \mathrm{SO}_{4}$ $0,1 \mathrm{M}$ yang ditambahkan ke dalam reaktor, suhu percobaan $\left(30-60^{\circ} \mathrm{C}\right)$, dan lama titrasi potensiometri yang dilakukan kurang lebih 120 menit.

\subsection{Cara Percobaan}

Tahap penelitian diawali dengan merangkai alat pengukuran konstanta disosiasi asam (pKa) kemudian pemanas dinyalakan sampai suhu yang diinginkan tercapai. Kalibrasi $\mathrm{pH}$ meter dilakukan sebelum penelitian dimulai. Larutan MEA 98\% sebanyak kurang lebih 0,5g

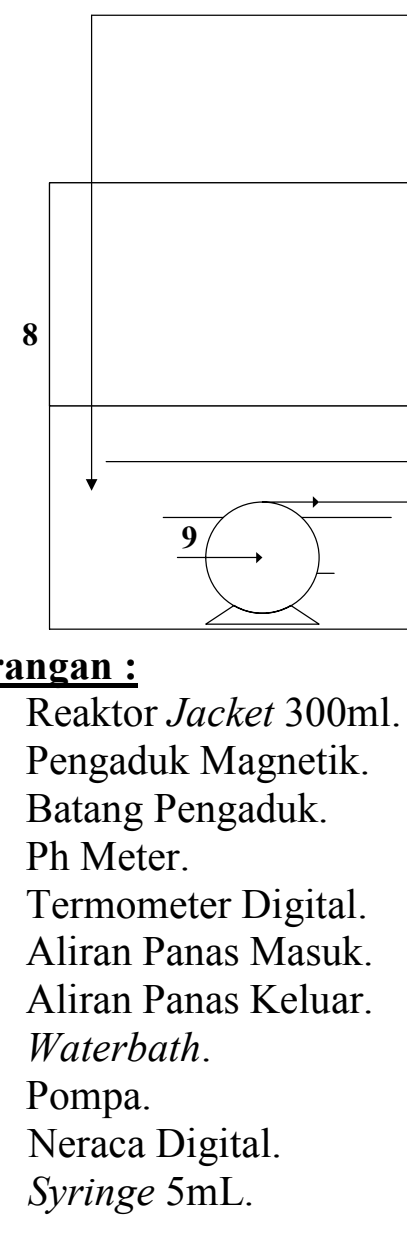

Gambar 3. Rangkaian Alat Percobaan. 
ditambahkan ke dalam reaktor jacket yang sudah berisi aquadest $50 \mathrm{~mL}$. Pada setiap percobaan diusahakan jumlah MEA yang ditambahkan konstan. Larutan diaduk sampai homogen. Selanjutnya ditambahkan sejumlah mL titran berupa larutan $\mathrm{H}_{2} \mathrm{SO}_{4} 0,1 \mathrm{M}$ dari syringe dilakukan berulang - ulang hingga titik ekuivalen terlampaui.

Pada saat mendekati titik ekuivalen, penambahan titran dilakukan dengan jumlah yang sangat sedikit agar titik ekuivalen tidak terlewati dan perubahan nilai $\mathrm{pH}$ tidak turun secara drastis.

Data - data penelitian yang diukur selama proses berlangsung antara lain : volume titran $\mathrm{H}_{2} \mathrm{SO}_{4}$ yang di tambahkan, $\mathrm{pH}$ setelah MEA ditambahkan dan setelah titran $\mathrm{H}_{2} \mathrm{SO} 4$ ditambahkan ke dalam reaktor pada setiap suhu percobaan. Percobaan dilakukan sebanyak dua kali untuk setiap suhu yang diinginkan. Data - data yang diperoleh selanjutnya digunakan untuk menghitung nilai konstanta disosiasi asam (pKa) monoethanolamine.

\section{PEMBAHASAN}

Studi yang dilakukan bertujuan untuk mengukur konstanta kesetimbangan asam (pKa) pada larutan MEA dengan variasi suhu $30,40,50 \mathrm{dn} 60^{\circ} \mathrm{C}$. Pengukuran konstanta disosiasi asam (pKa) dilakukan dengan menggunakan metode titrasi potensiometri.

Prinsip potensiometri pada penelitian ini didasarkan pada pengukuran potensial listrik antara elektroda yang potensialnya bergantung pada konsentrasi ion yang akan ditetapkan serta berdasarkan jenis senyawa yang hendak ditentukan (elektroda indicator) dengan elektroda yang potensialnya diketahui selama pengukuran energi potensialnya tetap atau bisa juga diartikan elektroda yang dicelupkan pada larutan (elektroda pembanding). Data - data yang diperoleh dalam titrasi akan menghasilkan grafik hubungan antara volume $\mathrm{H}_{2} \mathrm{SO}_{4} 0,1 \mathrm{M}$ dengan $\mathrm{pH}$ seperti terlihat pada gambar 4 - 6 .

Melalui grafik hubungan antara volume titran dan $\mathrm{pH}$ dapat ditentukan titik akhir titrasinya. Titik ekuivalen tercapai ketika terjadi perubahan $\mathrm{pH}$ secara drastis pada volume penambahan titran yang sedikit.

Metode titrasi potensiometri dipilih dalam penelitian ini karena penyajian langsung data penelitian dapat digunakan untuk penentuan titik ekivalen yang lebih akurat dan tidak membutuhkan indikator.

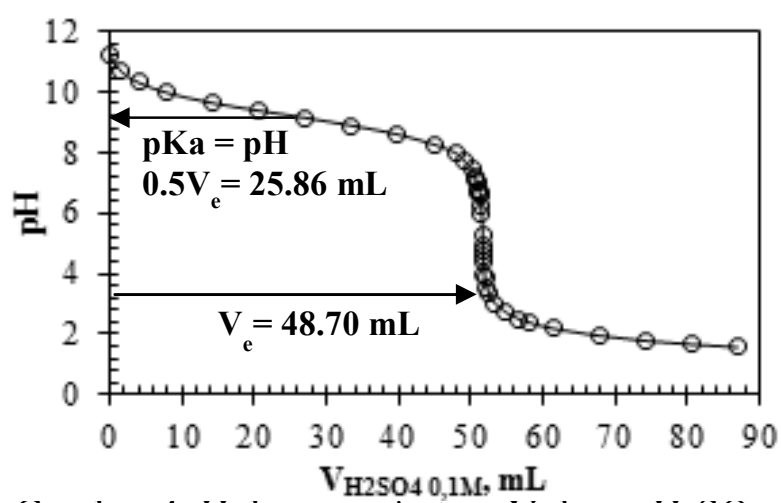

Gambar 4. Hubungan Antara Volume $\mathrm{H}_{2} \mathrm{SO}_{4}$ $0,1 \mathrm{M}$ dengan $\mathrm{pH}$ Pada Suhu $30^{\circ} \mathrm{C}$.

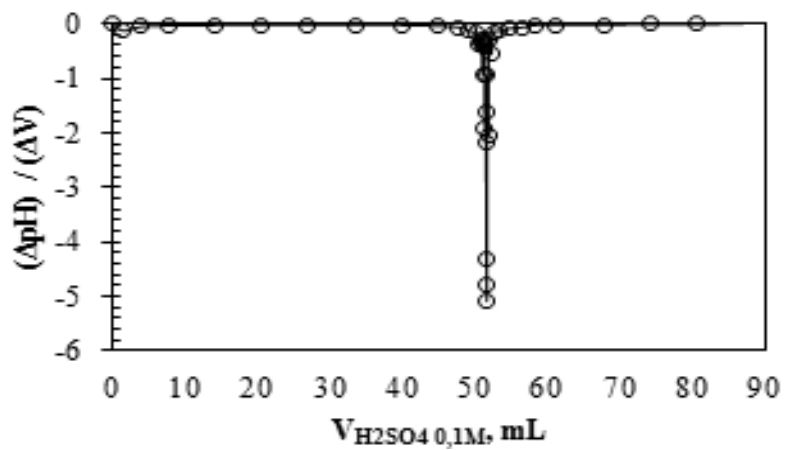

Gambar 5. Hubungan Antara $\Delta \mathrm{pH} / \Delta \mathrm{V}$ dengan Volume $\mathrm{H}_{2} \mathrm{SO}_{4}$ Pada Suhu $30^{\circ} \mathrm{C}$.

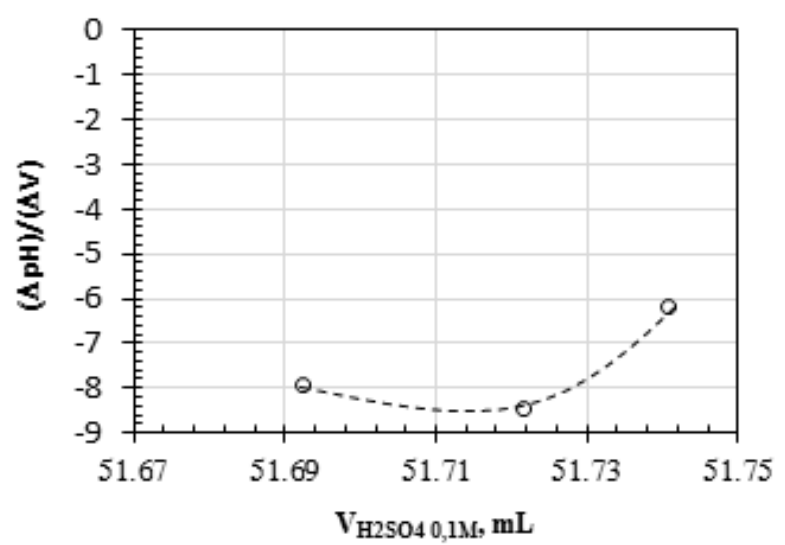

Gambar 6. Hubungan Antara $\Delta \mathrm{pH} / \Delta \mathrm{V}$ dengan Volume $\mathrm{H}_{2} \mathrm{SO}_{4}$ Pada Suhu $30^{\circ} \mathrm{C}$ di Sekitar Titik Ekuivalen. 
Pada saat titrasi berlangsung terjadi reaksi antara MEA dan $\mathrm{H}_{2} \mathrm{SO}_{4}$ sebagai titran, reaksi yang terjadi sebagai berikut :

$$
\mathrm{C}_{2} \mathrm{H}_{7} \mathrm{NO}+\mathrm{H}_{2} \mathrm{SO}_{4} \rightarrow \mathrm{C}_{2} \mathrm{H}_{7} \mathrm{NOH}^{+}+\mathrm{HSO}_{4}^{-}
$$

Nilai $\mathrm{pKa}$ dihitung dengan menggunakan data $\mathrm{pH}$ dan volume pada titik ekivalen. Titik ekivalen tercapai pada slope $\Delta \mathrm{pH} / \Delta \mathrm{V}$ terkecil. Nilai $\mathrm{pKa}$ dari asam akan sama dengan $\mathrm{pH}$ larutan pada saat penambahan volume $\mathrm{H}_{2} \mathrm{SO}_{4} 0,1 \mathrm{M}$ sebanyak setengah dari volume $\mathrm{H}_{2} \mathrm{SO}_{4} \quad 0,1 \mathrm{M}$ yang dibutuhkan untuk mencapai titik ekuivalen.

Dari Gambar 4 dan 5 diperoleh volume ekuivalen sebesar $45,05 \mathrm{~mL} \mathrm{H}_{2} \mathrm{SO}_{4} \quad 0,1 \mathrm{M}$ dan diperoleh setengah dari volume ekuivalen sebesar 22,52 $\mathrm{mL}(\mathrm{V}=0,5 \mathrm{Ve})$. Pada saat $\mathrm{V}=0,5 \mathrm{Ve}$, maka diperoleh $\mathrm{pH}$ larutan yang nilainya sama dengan nilai $\mathrm{pKa}$ yaitu sebesar 9,41 pada suhu $30^{\circ} \mathrm{C}$. Nilai pKa yang diperoleh dari percobaan ini mendekati nilai $\mathrm{pKa}$ MEA yang terdapat di literatur yaitu sebesar 9,35 pada suhu yang sama. Deviasi yang dihasilkan cukup kecil yaitu sebesar $0,65 \%$.

Konsentrasi air diabaikan pada perhitungan konstanta disosiasi asam (pKa), karena reaksi berjalan didalam larutan berair, dimana konsentrasi air relatif tidak berubah. Jika dilihat pada gambar 7 semakin tinggi suhu maka semakin kecil nilai pKa MEA. Pada umumnya jika suhu dinaikkan, laju reaksi bertambah cepat. Hal ini disebabkan semakin tinggi temperatur kecepatan gerak partikel - partikel pereaksi dan energi kinetik partikel akan ikut meningkat.

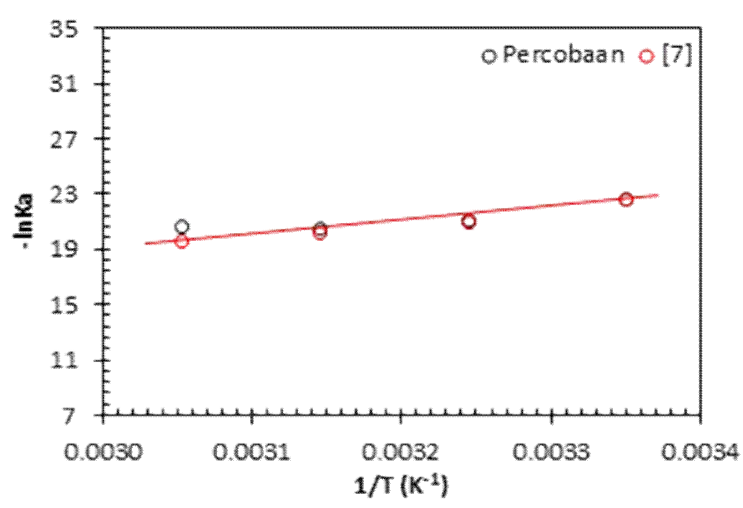

Gambar 7. Hubungan Antara - ln Ka Percobaan Dengan - In Ka Literatur Terhadap 1/T.

Pada percobaan ini deviasi terkecil didapat pada temperatur $30^{\circ} \mathrm{C}$ yaitu $0,22 \%$. Semakin tinggi konsentrasi asam maka semakin rendah nilai $\mathrm{pKa}$ yang dihasilkan. Air memiliki jumlah ion $\mathrm{H}^{+}$yang sama dengan $\mathrm{OH}^{-}$yaitu $10^{-7}$ mol per liter. MEA 98\% termasuk dalam basa lemah, sehingga penambahan $\mathrm{H}_{2} \mathrm{SO}_{4}$ dengan kadar $96 \%$ dalam penelitian ini akan menaikkan konsentrasi ion $\mathrm{H}+$ dan menurunkan ion $\mathrm{OH}^{-}$ Asam kuat $\mathrm{H}_{2} \mathrm{SO}_{4}$ akan mengikat $\mathrm{OH}^{-}$ sehingga nilai pKa mendekati nol. Asam yang lebih kuat memiliki nilai Ka yang lebih besar dan pKa yang lebih kecil.

Tabel 1. Perbandingan pKa Percobaan dan Literatur Pada Berbagai Suhu

\begin{tabular}{c|c|c|c|c}
\hline \multirow{2}{*}{$1 / \mathbf{T}$} & \multicolumn{2}{|c|}{ pKa } & \multicolumn{2}{c}{-In Ka } \\
\cline { 2 - 5 } & Percobaan & {$[7]$} & Percobaan & [7] \\
\hline 0,0033 & 9,83 & 9,80 & 22,62 & 22,57 \\
0,0032 & 9,18 & 9,07 & 21,13 & 20,88 \\
0,0031 & 8,88 & 8,77 & 20,45 & 20,20 \\
0,0030 & 8,99 & 8,53 & 20,71 & 19,63 \\
\hline
\end{tabular}




\section{KESIMPULAN}

Berdasarkan hasil penelitian yang telah dilakukan maka dapat diperoleh kesimpulan bahwa konstanta disosiasi asam (pKa) MEA yang dihasilkan pada suhu $30-60^{\circ} \mathrm{C}$ dapat digunakan sebagai dasar dalam perancangan absorber $\mathrm{CO}_{2}$. Pengaruh suhu terhadap nilai konstanta disosiasi asam (pKa) MEA yaitu semakin tinggi suhu maka semakin kecil nilai pKa yang dihasilkan.

Nilai pKa MEA yang dihasilkan dipengaruhi oleh kekuatan asam yang digunakan. Semakin kuat asam yang digunakan maka semakin kecil nilai pKa yang dihasilkan. Semakin cepat waktu percobaan dengan rentang perubahan $\mathrm{pH}$ yang kecil maka nilai $\mathrm{pKa}$ yang dihasilkan semakin akurat.

\section{SARAN}

Saran yang diberikan untuk penelitian selanjutnya adalah, perlu lebih teliti dan dikembangkan lebih lanjut agar MEA yang ditambahkan tidak menguap telalu banyak diantaranya dengan menggunakan peralatan standar untuk menjaga suhu dan dapat pula menghitung laju penguapan MEA untuk memperkecil error yang dihasilkan. Penelitian dilakukan dengan cepat agar larutan MEA tidak menguap terlalu banyak.

\section{Ucapan Terima Kasih}

Peneliti mengucapkan terima kasih kepada Program Studi Teknik Kimia, Fakultas Teknologi Industri, Universitas Islam Indonesia, Yogyakarta atas pendanaan penelitian ini melalui skema Penelitian Dosen dan Mahasiswa TA 2015/2016.

\section{DAFTAR PUSTAKA}

A. Tagiuri, M. Mohamedali, A. Henni. Dissociation Constant (pKa) and Thermodynamic Properties of Some Tertiary and Cyclic Amines from (298 to 333) K. J. Chem. Eng. Data, 2016, 61 (1), pp 247-254.

Alley, R., Climate Change : The Physical Science Basis. Contribution of Working Group I to the Fourth Assessment Report of the Intergovernmental Panel on Climate Change, 2007.

Astarita, G.; D.W. Savage; A Bisio. Gas Treating with Chemical Solvents. New York: Willey, 1983.

Harte, John; et al. (30-10-2006). "Shifts in plant dominance control carbon-cycle responses to experimental warming and widespread drought". Environmental Research Letters 1 (1). 014001, 2006.

Scheffer, Marten; et al. (26-05-2006). "Positive feedback between global warming and atmospheric $\mathrm{CO}_{2}$ concentration inferred from past climate change." (PDF). Geophysical Research Letters 33. doi:10.1029/2005g1025044, 2006.

Torn, Margaret; Harte, John (26-05-2006). "Missing feedbacks, asymmetric uncertainties, and the underestimation of future warming". Geophysical Research Letters 33 (10). L10703, 2006.

Wang; et al. Impact of DEA solutions with and without $\mathrm{CO}_{2}$ loading on porous polypropylene membranes intended for use as contactors. Journal of Membrane Science, 2003. 